\title{
PERAN SATUAN POLISI PAMONG PRAJA DALAM MENINGKATKAN KETERTIBAN PEDAGANG KAKI LIMA
}

( Studi Deskriptif di alun-alun barat Kota Serang)

\author{
Rini Andriani ${ }^{1}$, Lina Marlina ${ }^{2}$ \\ Universitas Banten Jaya \\ Serang, Banten \\ riniandriyanni123@gmail.com ${ }^{1}$, linamarlina@unbaja.ac.id²,
}

\begin{abstract}
This research was based on the background of the problem of order that is, there were still street vendors who sell in the west plaza of Serang city. The purpose of this study was to determine the role of Satpol PP in increasing orderliness of street vendors which were still sold in the west plaza of Serang city. This research method was descriptive with the factual depiction, data in the form of expressions, languages, and discourses that were precise and systematic. Qualitative research is research that is used to examine the scientific condition of the object, where the researcher was a qualitative instrument. The results of this study indicate the role of satpol PP in increasing orderliness of street vendors has been good at minimizing street vendors who sell in the west square of Serang city. The conclusion of this research confirms that the street vendors were not allowed to sell in the west square area of Serang city and to minimize the stubborn street vendors, the Satpol PPcarrying out the raids routine every day. The suggestion in this research was that the Satpol PP keeps monitoring and doing raids routine every day so that the street vendors will not sell in the west square of Serang city.
\end{abstract}

Keywords: Role of Satpol PP, Increasing Order of Street Vendors, Alun-Alun Barat Kota Serang

\section{PENDAHULUAN}

Seiring dengan perkembangan era reformasi dan globalisasi saat ini harus diakui gangguan trantibumas cenderung meningkat di setiap daerah atau kota, salah satu upaya penting untuk mengatasinya yaitu sangat diperlukan peningkatan kualitas aparat keamanan yang kuat. Tidak hanya dapat menjalankan tugas dengan baik, tapi juga dapat memberikan contoh, sikap, kepribadian dan tingkah laku yang baik di dalam masyarakat.
Dalam penyelenggaraan pemerintah daerah, seorang Kepala Daerah dibantu oleh perangkat daerah untuk menjalankan roda pemerintahan yang bertujuan mewujudkan pembangunan nasional. Salah satu perangkat daerah yang mempunyai peran penting dalam membantu pemerintahan daerah yaitu Satuan Polisi Pamong Praja (selanjutnya disingkat menjadi Satpol PP). Satpol PP merupakan salah satu perangkat yang dimiliki oleh Pemerintah Daerah 
dalam memelihara ketentraman dan ketertiban umum serta menegakkan Peraturan Daerah. Menurut UndangUndang Nomor 32 Tahun 2004 tentang Pemerintahan Daerah padapasal 148 ayat (1) menyatakan: "Bahwa untuk membantu kepala daerah dalam menegakkan Perda dan penyelenggaraan ketertiban umum dan ketentraman masyarakat dibentuk Satuan Polisi Pamong Praja".

Dalam Peraturan Pemerintah Nomor 6 Tahun 2010 tentang Satpol PP pada pasal 4 disebutkan: "Satpol PP mempunyai tugas menegakkan Perda dan menyelenggarakan ketertiban umum dan ketentraman masyarakat serta perlindungan masyarakat. "Maka di setiap provinsi dan kabupaten/kota dibentuk Satpol PP. Untuk itu dalam menghadapi berbagai situasi dalam menjalankan tugasnya, Satpol PP harus dapat mengambil sikap yang tepat dan bijaksana. Hal itu sesuai dengan paradigm baru Satpol PP yaitu menjadi aparat yang ramah, bersahabat, dapat menciptakan suasana batin dan nuansa kesejukan bagi masyarakat, namun tetap tegas dalam bertindak demi tegaknya peraturan yang berlaku. Oleh karena itu, dalam rangka mengantisipasi perkembangan dan dinamika masyarakat seiring dengan tuntutan era globalisasi dan otonomi daerah, setiap Satpol PP dituntut untuk semakin meningkatkan kinerjanya. Kemudian fungsi lainnya ialah penyusunan program, dan Satpol PP pun telah menyusun program tersebut diantaranya ialah program kegiatan pembinaan dan pengaturan PKL, begitu pula dengan Satpol PP Kota Serang juga mempunyai program kegiatan pembinaan dan pengaturan PKL untuk mewujudkan Kota Serang yang aman nyaman, tertib, indah dan bersih. Penelitian ini bertujuan :

1. Untuk mengetahui peran satuan polisi pamong praja dalam meningkatkan ketertiban pedagang kaki lima Kota Serang.

2. Untuk mengetahuiapa saja hambatan satuan polisi pamong praja dalam melakukan penertiban pedagang kaki lima Kota Serang.

3. Untuk mengetahui bagaimana strategi yang dilakukan satuan polisi pamong praja dalam meningkatkan ketertiban pedagang kaki lima Kota Serang.

Menurut Peraturan Pemerintah Nomor 6 Tahun 2010 pasal 1 ayat 8 mengenai Satpol PP dijelaskan Satpol PP adalah bagian perangkat daerah dalam menegakkan perda dan penyelenggaraan ketertiban umum dan ketentraman masyarakat. Selanjutnya dalam peraturan pemerintah No 6 Tahun 2010 pasal 1 ayat 10 Ketertiban umum dan ketentraman masyarakat adalah suatu 
keadaan dinamis yang memungkinkan pemerintah, pemerintah daerah, dan masyarakat dapat melakukan kegiatannya dengan tentram, tertib, dan teratur.

Satpol PP adalah bagian perangkat daerah dalam penegakan perda dan penyelenggaraan ketertiban umum dan ketentraman masyarakat sesuai dengan Peraturan Pemerintah Nomor 6 Tahun 2010 Pasal 1 Butir 8, Ketertiban dan ketentraman umum yang dimaksud dalam suatu daerah yaitu keadaan dinamis yang memungkinkan pemerintah, pemerintah daerah dan masyarakat dapat melakukan kegiatannya dengan tentram, tertib dan teratur.

Peraturan pemerintah No 06 Tahun 2010

Pasal 4 Satpol PP mempunyai tugas menegakkan Perda dan menyelenggarakan ketertiban umum dan ketenteraman masyarakat serta perlindungan masyarakat. Pada peraturan pemerintah No 06 Tahun 2010 Pasal 5 Dalam melaksanakan tugas sebagaimana dimaksud dalam Pasal 4, Satpol PP mempunyai fungsi:

a. Penyusunan program dan pelaksanaan penegakan Perda, penyelenggaraan ketertiban umum dan ketenteraman masyarakat serta perlindungan masyarakat;

b. Pelaksanaan kebijakan penegakan Perda dan peraturan kepala daerah; c. Pelaksanaan kebijakan penyelenggaraan ketertiban umum dan ketenteraman masyarakat di daerah;

d. Pelaksanaan kebijakan perlindungan masyarakat;

e. Pelaksanaan koordinasi penegakan Perda dan peraturan kepala daerah, penyelenggaraan ketertiban umum dan ketenteraman masyarakat dengan Kepolisian Negara Republik Indonesia, Penyidik Pegawai Negeri Sipil daerah, dan/atau aparatur lainnya;

f. Pengawasan terhadap masyarakat, aparatur, atau badan hukum agar mematuhi dan menaati Perda dan peraturan kepala daerah; dan

g. Pelaksanaan tugas lainnya yang diberikan oleh kepala daerah.

PKL adalah orang atau kelompok ekonomi lemah yang menjual kebutuhan sehari-hari, makanan atau jasa dengan modal yang relatif kecil, memiliki modal atau modal pinjaman dari pihak lain, yang menjual di tempat terlarang atau tidak. (Kartini Kartono, 1980:4). Satuan Polisi PamongPraja Ialah bagian perangkat di daerah pada konsentrasi pengukuhan"Peraturan Daerah", ketentraman masyarakat serta ketertibannya. Didasari PP nomor 6, 2010 pada pasal 3 3. Pedagang KakiLima Ialah orang yang memasarkan dagangannya pada 
daerah yang tidak diperbolehkan oleh pemerintah setempat. Seperti di sisi jalan umum, memakai peranti gerobak yang bisa didorong serta tenda. "Kamus Besar Bahasa Indonesia Kontemporer (1991)"

Satuan Polisi Pamong Praja (Satpol PP) Satuan Polisi Pamong Praja disingkat Satpol PP, adalah sebuah perangkat Pemerintah Daerah dalam memelihara ketentraman dan ketertiban umum serta menegakkan peraturan daerah. Satpol PP memiliki tugas-tugas berikut: 1 . Menjunjung Peraturan Daerah. 2. Mengatur Ketertiban Umum. 3. Mengatur Kedamaian dan Ketentraman Publik. 4. Pelindung Masyarakat. Dalam melakukan tugas-tugas di atas, Satuan Polisi Pamong Praja (Satpol PP) memiliki beberapa fungsi berikut ini : 1. Persiapan program dan pelaksanaan penegakan Peraturan Daerah dan Peraturan /Keputusan Walikota, pelaksanaan ketertiban umum dan perdamaian rakyat serta perlindungan masyarakat. 2 . Implementasi peraturan dan regulasi daerah /Keputusan walikota. 3. Implementasi kebijakan tentang pelaksanaan ketertiban umum dan keselamatan orangorang di daerah. 4. Pelaksanaan kebijakan perlindungan masyarakat. 5. Pelaksana koordinasi penerapan peraturan daerah dan Regulasi / Keputusan Walikota serta penyelenggaraan ketertiban umum dan kedamaian masyarakat dengan Kepolisian Republik Indonesia, penyidik, pegawai negeri dan / atau aparatur lain. 6. Pengawasan masyarakat, aparat, atau badan hukum untuk mematuhi dan mentaati penegakan Peraturan dan Regulasi Daerah / Keputusan Walikota. 7. Implementasi tugas lain yang diberikan oleh kepala daerah. Selain memiliki tugas dan fungsi, setiap anggota Satpol PP memiliki wewenang sebagai berikut: 1. Mengambil tindakan kontrol non-yudisial terhadap anggota masyarakat, aparat atau badan hukum yang melanggar peraturan daerah atau peraturan yang dibuat oleh Walikota. 2. Bertindak melawan warga negara, aparat atau badan hukum yang mengganggu ketertiban umum dan kedamaian masyarakat. 3. Fasilitas dan pemberdayaan kapasitas untuk menjalankan perlindungan masyarakat. 4. Melakukan tindakan investigasi terhadap warga masyarakat, aparat, atau badan hukum siapa yang diduga melanggar peraturan daerah atau keputusan Walikota. 5. Melakukan tindakan administratif terhadap penduduk, komunitas, aparat, atau badan hukum yang melanggar peraturan daerah atau keputuasan Walikota.

Kemudian menurut Yan Pieter Karafir (Soemitro, Styastie, 2002:10), menyatakan bahwa "Pedagang Kaki Lima adalah pedagang kecil yang menjual di tempat 
umum seperti di pinggir jalan, taman kota, toko, dan pasar tanpa izin dari pemerintah . Dalam kamus bahasa Indonesia yang besar (1987) diterbitkan oleh Balai Pustaka menyebutkan PKL berarti: 1. Toko depan (emper) berbelanja di sisi jalan (biasanya berukuran lima kaki), digunakan sebagai tempat penjualan. 2. Tepi pinggir jalan. Sedangkan dalam Kamus Besar Kontemporer, Peter Salim dan Yenny Salim (1991) menyebutkan trotoar yang berarti: a) Lantai beratap yang menghubungkan rumah. b) Toko Emper di sisi jalan. c) Tepi jalan. Jadi, PKL adalah pedagang yang biasanya berjualan di toko-toko (milik orang lain) atau berjualan di pinggir jalan.

PKL para pekerja di sektor informal yang banyak ditemui di perkotaan.PKL cenderung menempati lokasi yang tidak permanen dan tersebut hampir disetiap trotoar atau ruang-ruang terbuka yang bersifat umum. Penampilannya tampak dalam bentuk sarana dagangan sederhana dan umumnya masih bercirikan tradisional. Adon (2017:287).

Sektor informal muncul ke permukaan karena sektor formal tidak memberikan ruang lingkup yang cukup sehingga kegiatan ekonomi berlangsung di luar sektor yang terorganisasi. Sektor utama yang diisi oleh golongan kurang mampu ini terlihat semakin menjamur dinegara sedang berkembang. Karena kegiatannya dipandang ilegal, para pengamat menamakan kegitan ini sebagai kegiatan ekonomi bawah tanah atau underground economy, Rachbini dan Hamid (1994:25) Dalam Adon (2017:283).

Dalam literatur ekonomi, istilah sektor informal menunjuk pada aktivitas ekonomi yang berada diluar bentuk-bentuk organisasi produksi, distribusi,dan konsumsi yang nyata, terorganisasi, dan secara hukum legal, Holton (2006c:291) Dalam Sindung Haryanto (2011:230).

Istilah lain yang sering dipakai untuk menunjuk sektor informal ini salah satunya adalah shadow economy atau ekonomi bayang-bayang menunjuk pada fenomena sektor informal yang tidak mengikuti aturan-aturan yang dikeluarkan pemerintah. Keberadaannya sering dipandang "antara ada dan tiada", dalam sistem administrasi pemerintah, jelas keberadaan sektor ini tidak tercatat, tetapi realitasnya justru sektor inilah yang berfungsi sebagai penopang ketika ekonomi sedang menuju titik nadir dalam Sindung Haryanto (2011:230).

Di Indonesia, sudah ada kesepakatan tentang sebelas ciri pokok sektor informal, yaitu:

1. Kegiatan usaha tidak terorganisasi dengan baik karena timbulnya unit usaha tidak mempergunakan fasilitas atau 
kelembagaan yang tersedia di sektor formal.

2. Pada umumnya, unit usaha tidak mempunyai izin usaha.

3. Pola kegiatan usaha tidak teratur, baik dalam arti lokasi maupun jam kerja.

4. Pada umumnya, kebijaksanaan pemerintah untuk membantu golongan ekonomi tidak sampai ke pedagang kaki lima.

5. Unit usaha mudah keluar masuk dari satu sub-sektor ke lain sub-sektor.

6. Teknologi yang digunakan bersifat primitif.

7. Modal dan perputaran usaha relative kecil sehingga skala operasi relative kecil.

8. Pendidikan yang diperlukan untuk menjalankan usaha tidak memerlukan pendidikan formal karena pendidikan yang diperoleh dari pengalaman sambil kerja.

9. Pada umumnya, unit usaha termasuk golongan one-man enterprise dan kalau mengerjakan buruh berasal dari keluarga.

10. Sumber dana modal usaha yang umumnya berasal dari tabyngan sendiri atau lembaga keuangan yang tidak resmi.

11. Hasil produksi atau jasa terutama dikonsumsi oleh golongan masyarakat desa-kota berpenghasilan rendah dan kadang-kadang juga yang berpenghasilan menengah. Menurut Hidayat (1987) Dalam Sindung Haryanto(2011:232),

Semua orang bersedia bekerja dibawah perintah orang lain. Bagi mereka yang tidak bersedia bekerja sebagai anak buah dari orang lain, maka salah satu jalan keluarnya adalah bekerja mandiri di sektor informal. Kebanykan sektor informal memiliki ciri sebagai pekerjaan mandiri atau bisa dilakukan secara sendiri seperti PKL dengan beragam jenis komoditasnya, Dalam Damsar \& Indrayani (2017:201).

\section{METODE PENELITIAN}

Penelitian kualitatif merupakan penelitian yang berupaya menganalisis kehidupan sosial dengan menggambarkan dunia sosial dari sudut pandang atau interpretasi individu (informan) dalam latar ilmiah. Dengan kata lain, penelitian kualitatif berupaya memahami bagaimana seseorang individu melihat, memknai atau menggambarkan dunia sosialnya. Pemahaman ini merupakan hasil interaksi sosialnya.Memahami merupakan esensi dari penelitian kulitatif. Secara sederhana, proses memahami sangat mudah diucapkan, tetapi sesungguhnya sangat sulit untuk 
dilakukan dengan sebenar-benarnya. (Sudaryono 2018:91-92).

Dalam penelitian ini, peneliti menggunakan metode kualitatif dengan pendekatan deskriptif karena untuk melihat fakta dan keadaan di lapangan yang terjadi disaat penelitian berlangsung dengan menyuguhkan apa yang sebenarnya terjadi. Peneliti menafsirkan dan menguraikan data yang bersangkutan dengan situasi yang sedang terjadi sikap serta pandangan yang terjadi dalam suatu masyarakat.

Dalam penelitian ini, peneliti menggunakan metode kualitatif dengan pendekatan deskriptif karena untuk melihat fakta dan keadaan di lapangan yang terjadi disaat penelitian berlangsung dengan menyuguhkan apa yang sebenarnya terjadi. Peneliti menafsirkan dan menguraikan data yang bersangkutan dengan situasi yang sedang terjadi sikap serta pandangan yang terjadi dalam suatu masyarakat.

Dalam teknik pengumpulan data penelitian ini menggunakan berbagai teknik, yaitu wawancara, observasi, dan dokumentasi. Ketiga teknik tersebut digunakan untuk memperoleh data dan informasi yang saling menunjang dan melengkapi tentang peran satuan polisi pamong praja dalam penertiban pedagang kaki lima untuk menciptakan kota serang yang tertib.

\section{Observasi}

Observasi yaitu melakukan pengamatan secara langsung ke objek penelitian untuk melihat dari dekat kegiatan yang dilakukan. Apabila objek penelitian bersifat perilaku, tindakan manusia, dan fenomena alam (kejadian-kejadian yang ada dialam sekitar), proses kerja, dan penggunaan responden kecil. Observasi atau pengamatan merupakan suatu teknik atau cara mengumpulkan data dengan jalan mengadakan pengamatan terhadap kegiatan yang sedang berlangsung. Observasi dapat dilakukan dengan partisipasi ataupun nonpartisipasi.Dalam observasi partisipasi pengamat ikut serta dalam kegiatan yang sedang berlangsung, pengamat ikut sebagai peserta rapat atau peserta pelatihan. Dalam observasi nonpartisipatif pengamat tidak ikut serta dalam kegiatan, dia hanya berperan mengamati kegiatan, tidak ikut dalam kegiatan (Sudaryono,2018:216)

Observasi meupakan suatu proses yang kompleks, suatu proses yang tersusun dari berbagai proses bilogis dan psikhologis. Dua diantara yang terpenting adalah prosesproses pengamatan dari ingatan, Sutrisno Hadi (1986) dalam Sugiyono (2011:145).

Peneliti menggunakan observasi deskriptif, karena observasi deskriptif dilakukan peneliti pada saat memasuki situasi sosial tertentu sebagai objek penelitian. Pada 
tahap ini peneliti belum membawa masalah yang akan diteliti maka peneliti melakukan penjelajah umum, dan menyeluruh, melakukan deskripsi terhadap semua yang dilihat, didengar, dan dirasakan. Semua data direkam, oleh karena itu hasil dari observasi ini disimpulkan dalam keadaan yang belum tertata.Observasi tahap ini sering disebut sebagai grand tour observation, dan peneliti menghasilkan kesimpulan pertama.Bila dilihat dari segi analisis maka peneliti melakukan analisis Domain, sehingga mampu mendeskripsikan terhadap semua yang ditemui. Pada tahap ini peneliti melakukan pra observasi untuk meyakinkan bahwa apakah alun-alun kota serang sudah tertib dan bebas dari pedagang kaki lima yang berjualan. Observasi dilakukan pada hari kamis 31 januari 2019 dan tempat observasi langsung dilaksanakan di alunalun barat Kota Serang dan kantor satuan polisi pamong praja Kota Serang.

\section{Wawancara}

Wawancara adalah suatu cara pengumpulan data yang digunakan untuk memperoleh informasi langsung dari sumbernya. Wawancara ini digunakan bila ingin mengetahui hal-hal dari responden secara lebih mendalam serta jumlah responden sedikit, dalam Sudaryono (2017:212). Ada beberapa faktor yang akan mempengaruhi arus informasi dalam wawancara, yaitu: pewawancara, responden, pedoman wawancara, dan situasi wawancara, Hadeli (2006) dalam Sudaryono (2017:212).

Dalam melakukan wawancara yang menjadi narasumber yaitu anggota Satpol PP, salah satu pedagang kaki lima dan masyarakat yang melintasi alun-alun barat Kota Serang. Pada tahap ini peneliti sudah melakukan tindakan awal yaitu wawancara awal kepada informan dengan mewawancarai salah satu pedagang kaki lima yang berjualan di alun-alun barat Kota Serang dan mewawancarai kepala satuan polisi pamong praja.

\section{Dokumentasi}

Dokumen merupakan catatan peristiwa yang sudah berlalu. Dokumen bisa berbentuk tulisan, gambar, atau karya-karya monumental dari seorang."Dokumentasi adalah ditujukan untuk memperoleh data langsung dari tempat penelitian, foto-foto, film dokumenter, data yang relevan penelitian.Dokumen merupakan catatan peristiwa yang sudah berlalu.Dokumen bisa berbentuk tulisan, gambar, atau karya-karya monumental dari seseorang" dalam Sudaryono (2018:219). Dokumentasi adalah suatu metode pengumpulan data kulitatif dengan melihat atau menganalisis dokumen-dokumen yang dibuat oleh subjek 
sendiri atau oleh orang lain tentang subjek. Sejumlah besar fakta dan data tersimpan dalam bahan yang berbentuk dokumentasi.Dokumen merupakan catatan peristiwa yang sudah berlalu.Dokumen bisa berbentuk tulisan, gambar, atau karya-karya monumental dari seorang.Dokumen yang berbentuk tulisan misalnya catatan harian, sejarah kehidupan (life histories), ceritera, biografi, peraturan, kebijakan.Dokumen yang berbentuk karya misalnya karya seni, yang dapat berupa gambar, patung, film dan lain-lain.Studi dokumen merupakan pelengkap dari penggunaan metode observasi dan wawancara dalam penelitian kualitatif, Menurut Sugiyono (2013:240).

\section{HASIL PENELITIAN DAN} PEMBAHASAN

Data hasil penelitian yang ada dilapangan diketahui bahwa Kepala Satuan Polisi Pamong Praja sudah melaksanakan peranan dan tanggungjawabnya secara optimal untuk meminimalisir para pedagang kaki lima dengan adanya peningkatan penertiban dapat mengurangi atau meminimalisir para pedagang kaki lima yang berjualan di alunalun barat Kota Serang agar alun-alun barat Kota Serang dapat terlihat indah dan tidak kumuh.

Dengan adanya peningkatan penertiban yang dilakukan Satpol PP maka aktivitas para pedagang kaki lima di alun-alun barat Kota Serang mulai berkurang. Sehingga tujuan Satpol PP dalam meningkatkan ketertiban pedagang kaki lima tecapai. Sesuai dengan peran Satpol PP maka sudah menjadi tanggung jawab Satpol PP di dalam menjalankan program kerja yang ada di kantor Satpol PP sehingga para pedagang kaki lima menyadari akan tujuan Satpol PP dalam melakukan penertiban dengan penuh kesadaran dan mau mentaati peraturan yang sudah dibuat serta memilih tempat yang sudah disediakan. Dengan demikian, adanya peningkatan penertiban yang dilakukan oleh Satpol PP dapat memberikan kontribusi dalam meningkatkan ketertiban pedagang kaki lima sehingga mampu meminimalisir para pedagang kaki lima.

Jadi dapat di tarik kesimpulan bahwasannya Satpol PP selalu melaksanakan razia dan selalu memantau para pedagang kaki lima yang bandel yang tetap berjualan di alunalun barat kota serang meskipun sudah diberi surat peringatan dan razia sekalipun, akan tetapi Satpol PP tidak pantang menyerah tetap melaksanakan tugasnya dalam melaksanakan penertiban pedagang kaki lima guna meminimalisir para pedagang kaki lima yang berjualan di tempat yang tidak di perizinkan. 


\section{PEMBAHASAN}

Dalam lingkungan masyarakat ketertiban perlu dilaksanakan demi terciptanya kota yang indah, bersih dan nyaman, sebab apabila ketertiban umum tidak dilakukan maka lingkungan akan terlihat kumuh dan kotor. Oleh karena itu Satpol PP berperan penting dalam menyelenggarakan ketertiban umum dan ketentraman masyarakat. Hasil penelitian ini menjawab rumusan masalah maka dapat dijelaskan sebagai berikut:

\section{Peran Satuan Polisi Pamong Praja} Dalam Meningkatkan Ketertiban Pedagaang Kaki Lima Di Alun-Alun

\section{Barat Kota Serang}

Peran Satpol PP bagian dari perangkat aparatur di daerah yang memiliki kewajiban untuk melaksanakan penegakan peraturan daerah dan menyelenggarakan ketertiban umum serta menciptakan ketentraman di masyarakat. Ketertiban umum dan Ketentraman masyarakat merupakan sebuah keadaan dinamis yang dimana memungkinkan pemerintah daerah dan masyarakat daerah dapat melakukan kegiatanya dengan tentram, tertib, dan teratur. Oleh karena itu tugas Satpol PP dapat disebut pemeliharaan dan penyelenggaraan ketenteraman dan ketertiban umum dalam mengontrol setiap aktivitas masyarakat yang menyimpang dan melanggar ketertiban umum. Dengan apa yang ditunjukkan Satpol PP dalam melakukan penertiban, diharapkan mampu mempengaruhi masyarakat untuk mentaati peraturan yang ada. Upaya yang dilakukan untuk meningkatkan ketertiban pedagang kaki lima antara lain: (a) pelaksanaan kebijakan penegakan Perda dan peraturan kepala daerah. (b) pelaksanaan kebijakan penyelenggaraan ketertiban umum dan ketenteraman masyarakat di daerah. (c) peran satuan polisi pamong praja dalam menegakkan perda. Peran Satpol PP dalam meningkatkan ketertiban pedagang kaki lima seperti melakukan pengawasan, melakukan razia kepada para pedagang kaki lima yang berjualan diatas trotoar atau bahu jalan. Karena peran Satpol PP didalamnya sebagai penegak perda dan penyelenggra ketertiban umum dan ketentraman masyarakat. Satpol PP sebagai pelaksanaan kebijakan penyelenggaraan ketertiban umum dan ketenteraman masyarakat. Berperan penting dalam menertibkan dan mengamankan, jika Satpol PP tidak melaksanakan kebijakan pelanggaran ketertiban umum dan ketentraman 
masyarakat maka kota tidak akan tertib, bersih dan indah. Satpol PP dalam menegakkan perda artinya perda harus ditegakkan agar mampu meminimalisir terjadinya pelanggaran ketertiban umum. Jadi ketika perda ditegakkan masyarakat yang sering melanggar ketertiban harus sadar hukum agar terciptanya suatu keindahan, ketertiban dan ketentraman.

Dari penjelasan diatas dapat di simpulkan bahwa peran Satpol PP itu sangat penting dimana Satpol PP harus mampu meneggakkan perda dan menyelenggarakan ketertiban umum, karena dengan ditegakkannya perda dan dilaksanakannya penyelenggaran ketertiban umum maka tidak akan ada lagi masyarakat yang melanggar ketertiban umum. Peran Satpol PP disini mempunyai cara untuk meningkatkan ketertiban umum dengan cara melakukan razia setiap hari dan melaksanakan penyelenggaraan ketertiban umum, sehingga terciptanya kota yang aman, bersih dan tertib.

\section{Hambatan Satuan Polisi Pamong} Praja Dalam Melakukukan Penertiban Pedagang Kaki Lima Di Alun-Alun Barat Kota Serang

Berdasarkan hasil wawancara, adapun hambatan-hambatan yang dialami Satpol
PP dalam meningkatkan ketertiban pedagang kaki lima, menurut data dari hasil penelitian menyatakan sebagai berikut:

a. Faktor ekonomi, karena para pedagang kaki lima yang mempunyai modal pas-pasan yang menyebabkan mereka tidak mampu menyewa kios sehingga mereka memutuskan untuk berjualan ditemnpat yang dilarang seperti misalnya dibahu jalan atau di atas trotoar, sehingga mereka menjadi bandel dan tetap berjualan di alunalun barat Kota Serang.

b. Kurangnya kesadaran hukum, karena para pedagang kaki lima yang berjualan ditempat yang tidak diperijinkan tidak sadar akan hukum bahwa berjualan diatas trotoar atau pinggir jalan itu merupakan pelanggaran ketertiban umum.

c. Faktor masyarakat, pedagang kaki lima yang tetap melanggar ketertiban umum terkadang menjadi hambatan bagi Satpol PP dalam upaya meningkatkan ketertiban umum. Faktor masyarakat berpengaruh bagi PKL yang tetap memilih berjualan ditempat tersebut karena mungkin dianggap tempat tersebut ramai pembeli dan tidak 
perlu membayar sewa tempat.

Faktor masyarakat disini berupa kesadaran warga masyarakat untuk mematuhi suatu peraturan perundang-undangan. Pada umumnya apabila kesadaran warga masyarakat terhadap hukum tinggi mengakibatkan warga masyarakat mematuhi ketentuan perundangundangan yang berlaku. Akan tetapi, apabila kesadaran warga masyarakat terhadap hukum rendah maka derajat kepatuhan terhadap peraturan perundang-undangan yang berlaku juga rendah.

\section{Strategi Satuan Polisi Pamong Praja} dalam Meningkatkan Ketertiban Pedagang Kaki Lima.

Strategi dalam meningkatkan ketertiban pedagang kaki lima di alun-alun barat Kota Serang yang dilakukan Satpol PP adalah dengan cara memberikan surat peringatan dahulu, halo-halo kemudian melaksanakan razia hal itu dilakukan untuk meminimalisir pedagang kaki lima yang berjualan di alun-alun barat Kota Serang.

Ketertiban dan ketentraman merupakan salah satu penangkal, pencegah dan penanggulangan segala bentuk pelanggaran hukum dan bentuk-bentuk gangguan lainnya yang dapat meresahkan masyarakat, hal ini sesuai tujuan ketertiban dan ketentraman dalam mencapai ketentraman serta membina kekuatan masyarakat. Ketertiban adalah suasana yang mengarah kepada peraturan dalam masyarakat menurut norma yang berlaku sehingga menimbulkan motivasi bekerja dalam rangka mencapai tujuan yang diinginkan. Peran Satpol PP dalam upaya meningkatkan ketertiban umum harus memiliki strategi agar penyelenggaraan ketertiban umum dapat berjalan dengan baik, salah satu startegi yang dilakukan oleh Satpol PP yaitu patrol setiap hari. Dalam usaha mencapai tujuan tersebut, berbagai upaya telah dilakukan oleh pemerintah, termasuk di dalamnya pembentukan aparat pemerintah baik sebagai abdi Negara maupun abdi masyarakat demi menjaga ketertiban dan keamanan masyarakat. Sebagai abdi negara dan abdi masyarakat, peran aparatur pemerintah haruslah berfokus kepada pelayanan publik. Oleh karena itu strategi untuk meminimalisir pedagang kaki lima sangatlah penting agar terciptanya kota serang yang aman, tertib dan indah.

\section{SIMPULAN}


Dari hasil penelitian yang penulis lakukan mengenai Peran Satuan Polisi Pamong Praja Dalam Meningkatkan Ketertiban Pedagang Kaki Lima di ALun-alun Barat Kota Serang dapat disimpulkan bahwa:

1. Peran Satuan polisi pamong praja dalam meningkatkan ketertiban pedagang kaki lima di alun-alun barat kota serang adalah bahwasannya peran satpol pp sangat penting dan sangat dibutuhkan karena tugas satpol pp itu sendiri adalah untuk menegakkan perda dan menyelenggarakan ketertiban umum dan ketentraman masyarakat, oleh karena itu satpol pp melakukan penertiban secara rutin untuk meminimalisir para pedagang kaki lima yang masih tetap berjualan di area alun-alun barat kota serang.

2. Hambatan yang terjadi pada saat satuan polisi pamong praja melakukukan penertiban pedagang

\section{DAFTAR PUSTAKA}

Haryanto, Sindung. (2011). Sosiologi Ekonomi. Jogjakarta: ArRuuz Media

Indonesia. (2012). Undang-Undang Otonomi Daerah. Bandung: Fokusmedia

Damsar \& Indrayani.(2017). Pengantar SosiologiPerkotaan.Jakarta:Kence na

Fahmi Susanti, (2019). Peran Satuan Polisi Pamong Praja Dalam Penataan kaki lima di alun-alun barat kota serang adalah ketika melakukan razia ada saja para pedagang kaki lima yang melanggar peraturan dan tetap memilih berjualan di tempat yang tidak di perizinkan dan juga karena mereka tidak punya tempat untuk berjualan mereka jadikan alasan untuk tetap berjualan di tempat tersebut, tentunya harus segera diatasi agar para pedagang kaki lima mau berjualan di tempat yang sudah disediakan dan mendapatkan izin.

3. Strategi yang dilakukan satuan polisi pamong praja dalam meningkatkan ketertiban pedagang kaki lima adalah dengan cara memberikan surat peringatan dahulu, halo-halo kemudian melaksanakan razia hal itu dilakukan untuk meminimalisir pedagang kaki lima yang berjualan di alun-alun barat kota serang.

Pedagang Kaki Lima Studi Kasus Pada Kota Tangerang Selatan Proceeding Universitas Pamulang Vol 1, No 1 .Http://Openjournal.Unpam.Ac.Id/I ndex.Php/Proceedings/Article/Vie $\mathrm{w} / 5302$

Sudaryono.(2018).MetodologiPenelitian.De pok: PT RajaGrafindoPersada

PeraturanPemerintah No 06 Tahun 2010 Tentang SatuanPolisiPamongPraja Undang-undang No.32 Tahun 2004 TentangPemerintahan Daerah 
Sugiyono. (2011). Metodologi Penelitian Kuantitatif Kualitatif Dan $R \& D$. Bandung :Alfabeta

Sugiyono. (2013). Metode Penelitian Pendidikan, Pendekatan Kuantitatif, Kualitatif, dan $R \& D$. Bandung:Alfabeta.

Unik Desthiani., (2019). Peran Komunikasi Satuan Polisi Pamong Praja (Satpol Pp) Dalam Memberikan Pembinaan Kepada Pedagang Kaki Lima (PKL)., Jurnal Sekretari Universitas Pamulang Vol 6, No 2 http://www.openjournal.unpam.ac.i d/index.php/Sekretaris/article/view/ 5540 